\title{
A GEO-HISTÓRIA DA ORGANIZAÇÃO ODEBRECHT: migração, negócios e o "trancafiamento" da natureza
}

\section{LA GEO-HISTORIA DE LA ORGANIZACIÓN ODEBRECHT: migración, negócios y el "trancafiamento" de la naturaleza}

\author{
Aline dos Santos Lima ${ }^{1}$ \\ Professora IF Baiano Campus Santa Inês \\ Projeto GeografAR/POSGEO/UFBA/CNPq \\ Doutora Geografia POSGEO/UFBA \\ aline.lima@ifbaiano.edu.br
}

\section{Resumo}

Algumas concepções teóricas tratam a questão agrária como uma discussão desconectada espaço-temporalmente do século XXI. Entretanto, as questões relativas ao acesso à terra estão cada vez mais atuais, especialmente quando empresas de escala mundial passam a se apropriar desse bem da natureza como objeto de ampliação, expansão e reprodução do seu capital. Nesse sentido, o objetivo deste artigo é fazer uma leitura geográfica da história da Organização Odebrecht com o propósito de evidenciar como Norberto Odebrecht, fundador do grupo, criou uma empresa de abrangência mundial e, ao mesmo tempo, passou a promover o trancafiamento da natureza a partir da monopolização do território e da territorialização do capital no campo brasileiro.

Palavras-chave: Organização Odebrecht. Geo-história. Monopolização do território. Territorialização do capital.

\section{Ponencia}

Algunas concepciones teóricas tratan la cuestión agraria como una discusión desconectada espacio-temporal del siglo XXI. Sin embargo, las cuestiones relativas al acceso a la tierra son cada vez más actuales, especialmente cuando empresas de escala mundial pasan a apropiarse de ese bien de la naturaleza como objeto de ampliación, expansión y reproducción de su capital. En ese sentido, el objetivo de este artículo es hacer una lectura geográfica de la historia de la Organización Odebrecht con el propósito de evidenciar cómo Norberto Odebrecht, fundador del grupo, creó una empresa de alcance mundial y, al mismo tiempo, pasó a promover el trancafiamiento de la naturaleza a partir de la monopolización del territorio y de la territorialización del capital en el campo brasileño.

Palabras-clave: Organización Odebrecht. Geo-historia. Monopolización del territorio. Territorialización del capital. 


\section{INTRODUÇÃO}

A concentração da propriedade da terra tem origens históricas e se reproduzem com o processo de expansão do capitalismo no campo, confirmando a permanência de uma questão agrária. Por questão agrária se entende as questões relativas às relações sociais de produção, ou seja, envolve, dentre outros, como e de que forma se produz no campo. Aspectos que remetem à estrutura de propriedade da terra e às relações sociais de produção que são estabelecidas entre os distintos e antagônicos grupos sociais que coexistem no tempo-espaço (LIMA, 2017).

Desse modo, a questão agrária tem como "pano de fundo" a contradição estrutural do modo de produção capitalista que se reproduz pela concentração dos meios de produção (terra e água) e pela exploração da força de trabalho. Porém, algumas concepções teóricas tratam a questão agrária como uma discussão desconectada espaçotemporalmente do século XXI (BUAINAIN et al, 2013), o que não corresponde à realidade objetiva, especialmente quando se observa que empresas de escala mundial passam a ser apropriar da terra como objeto de ampliação, expansão e reprodução do seu capital.

O objetivo deste artigo é fazer uma leitura geográfica da história da Organização Odebrecht com o propósito de evidenciar como Norberto Odebrecht, "fundador" do grupo, criou uma empresa de escala mundial e, ao mesmo tempo, passou a territorializar o capital e a monopolizar o território no campo brasileiro. Esses processos têm promovido o "trancafiamento" da natureza na medida em que a Organização investe no monocultivo de açúcar (monopolização do território) e envereda para o mercado de terras (territorialização do capital).

A pretensão de construir uma geo-história da Organização Odebrecht exige três colocações. Em primeiro lugar, considera-se que a geografia histórica é o instrumental metodológico mais apropriado para dar conta da intrincada análise de movimentos, características econômicas, políticas e culturais que se sobrepõem na produção do espaço ${ }^{2}$ (MORAES, 2000).

Outra questão a ser pontuada é que a produção do espaço é compreendida à luz da teoria geográfica. A construção de uma teoria geográfica do espaço e a consolidação da Geografia como ciência social tem suas bases nas proposições do filósofo francês Henri Lefebvre (1901-1991). Para Lefebvre (2006 [1974], p. 50), “o espaço (social) é um 
produto (social)". É através do trabalho (espaço da vida) que o homem transforma a natureza (espaço físico) e produz o espaço. Nas palavras do próprio Lefebvre (2006 [1974], p. 57), o espaço social contém dois tipos de relações a partir das quais o homem interage/modifica a natureza: a) "as relações sociais de reprodução, a saber, as relações bio-fisiológicas entre os sexos, as idades, com a organização específica da família"; b) as "relações de produção, a saber, a divisão do trabalho e sua organização, portanto, as funções sociais hierarquizadas".

Milton Santos, ao geografizar as proposições de Henri Lefebvre e construir sua teoria geográfica, afirma que o espaço "reúne a materialidade e a vida que a anima". Em outros termos, o espaço é “formado por um conjunto indissociável, solidário e também contraditório, de sistemas de objetos e sistemas de ações, não considerados isoladamente, mas como o quadro único no qual a história se dá" (SANTOS, 1997 [1996], p. 51).

Na medida em que o espaço é formado, inseparavelmente, pelas coisas (os objetos geográficos naturais e artificias) mais a sociedade, ele é considerado uma totalidade. Essa totalidade pode ser fragmentada e, depois, reconstituída a partir da análise teóricometodológica ${ }^{3}$. Para isso, é fundamental identificar os elementos que compõem o espaço. De acordo com Santos (2008, p. 16-17), os homens, as firmas, as instituições, o meio ecológico e as infraestruturas são os elementos do espaço.

A análise geo-histórica da Organização Odebrecht se dá a partir da fragmentação/reconstituição do todo. Ou seja, na medida em que Norberto Odebrecht (um decididor) reuniu um grupo de operários (homens) dispostos a produzir espaço (meio ecológico) fornecendo força de trabalho para uma construtora (firma) de origem familiar que se transformou numa holding que tanto materializa o trabalho humano (infraestrutura) quanto difunde normas (instituição) capazes de, dentre outros aspectos, ampliar o histórico processo de "trancafiamento" da natureza no campo brasileiro.

Para Mitidiero Júnior (2016, p. 17), o "trancafiamento" da natureza é o "aumento de investimentos densos de capital nos espaços rurais ou em atividades econômicas voltadas à exploração de bens naturais". Esse processo não é novo na história da humanidade. A diferença é que a privatização problematizada pelo geógrafo é um reflexo do colapso do capital global acirrado com a "crise do mercado imobiliário e do mercado de créditos norte-americano", bem como o seu alastramento por outras economias. Consequentemente, segundo o autor, o capital aplicado na esfera financeira teve suas 
possibilidades de reprodução ampliada retraída de forma assustadora para muitos investidores.

A saída para essa crise estrutural, de acordo com os argumentos desenvolvidos por Mitidiero Júnior (2016, p. 18-19) em seu ensaio, é a "apropriação da natureza de forma privada e mercadológica”. Nesse sentido, “investir em bens da natureza poderá ser mais seguro do que investir em outros setores da economia" (MITIDIERO JÚNIOR, 2016, p. 27-28). Sendo essa crise estrutural, "obrigatoriamente, passaremos por transformações radicais na forma de organização social da produção de valor, na estruturação do espaço (território) no qual as sociedades se desenvolvem, e no cotidiano da vida social como um todo", pois busca-se transformar "todas as dimensões da natureza em propriedade privada possível de auferir renda", a exemplo da terra (dimensão da natureza mais apropriada privadamente), da água (e da possibilidade de se tornar uma commodity), do ar (objeto de negociação em bolsas de valores) e da fotossíntese (captada no mercado de títulos chamado de crédito de carbono) (MITIDIERO JÚNIOR, 2016, p. $19 ; 21)$

No caso em apreço, esse processo se dá na medida em que Norberto Odebrecht assume a posição de decididor. Segundo Santos (1997 [1996], p. 65), cabe aos decididores "escolher o que vai ser difundido e, muito mais (...) escolher a ação que, nesse sentido, se vai realizar". Nessa condição, o engenheiro-empresário decidiu pelo "trancafiamento" da natureza na medida em que tem promovido a territorialização do capital e a monopolização do território.

Os mecanismos de territorialização do capital monopolista na agricultura e de monopolização do território pelo capital monopolista é bastante debatido por geógrafos que, direta ou indiretamente, discutem a questão agrária (OLIVEIRA, 1995, 2002, 2012; PAULINO, 2003; SUZUKI, 2007; CAMACHO, 2013). No âmbito da Geografia, a elaboração desses mecanismos foi construída a partir das teorizações de Ariovaldo Umbelino de Oliveira. Coube a esse geógrafo o papel trazer, para a ciência geográfica, o debate que estava sendo travado sociologicamente por José de Souza Martins acerca do processo desigual e contraditório do desenvolvimento do capitalismo no campo (CAMACHO, 2013).

Martins (1979, p. 21), ao abordar teoricamente as contradições do capitalismo a partir do colonato nas fazendas de café, salienta que o modo de produção capitalista "cria 
a um só tempo as condições da sua expansão, pela incorporação de áreas e populações às relações comerciais, e os empecilhos à sua expansão, pela não mercantilização de todos os fatores envolvidos, ausente o trabalho caracteristicamente assalariado". Foi a partir dessas colocações e de um diálogo constante com o citado sociólogo, que Oliveira (1995, 2002) transpôs esse debate para a Geografia.

Há situações de territorialização do capital monopolista na agricultura quando indústria e agricultura são partes ou etapas de um mesmo processo (OLIVEIRA, 1995, 2002). Isso significa que "capitalista da indústria, proprietário de terra e capitalista da agricultura têm um só nome, são uma só pessoa. Para produzir utilizam-se do trabalho assalariado, dos bóias-frias que moram/vivem nas cidades" (OLIVEIRA, 1995, p. 283).

As situações de monopolização do território pelo capital monopolista ocorrem quando o campesinato entrega sua produção às multinacionais (OLIVEIRA, 1995, 2002). Isso significa que "capitalista industrial é uma pessoa, proprietário da terra e trabalhador são uma única pessoa". Mas, também, é possível que os camponeses arrendem terra para plantar com o trabalho de suas famílias. Assim, "temos como personagens sociais no processo: o capitalista industrial, o proprietário da terra-rentista, que vive da renda em dinheiro recebida pelo aluguel da terra, e o camponês rendeiro, que com a família trabalha a terra"4 (OLIVEIRA, 1995, p. 283).

Mais recentemente, Oliveira (2012) tem discutido esse processo à luz da mundialização da agricultura. Antes, na territorialização do capital monopolista, o proprietário de terra e o capitalista da agricultura/indústria era uma só pessoa (OLIVEIRA, 1995, 2002). Com o mecanismo de territorialização dos monopólios na agricultura brasileira, está em voga uma nova ordem internacional marcada por fusões, associações e aquisições feitas com a participação do Estado, através de recursos de bancos públicos e/ou de fundos de pensão dos trabalhadores das estatais (OLIVEIRA, 2012).

Além disso, a agricultura sob o capitalismo monopolista mundializado passou a estruturar-se sobre três pilares: a) a produção de alimentos passou a ser mercadoria adquirida no mercado mundial (commodities); b) as bolsas de mercadorias e futuro passaram a controlar os preços mundiais das commodities; c) a constituição dos monopólios mundiais permitiu o controle da produção das commodities (OLIVEIRA, 2012).

Outro ponto que merece destaque é a aliança de classe de setores da burguesia brasileira com a mundial. Dessa relação, segundo Oliveira (2012, p. 10), começaram a 
“nascer", a partir de 2007, "novas empresas nacionais". Estas empresas de capital aberto "passam a atuar no mercado de terras, no preparo da propriedade para produção, na produção em si e na comercialização”. Com base em Oliveira (2012, p. 11-14), essa aliança para o rentismo vem sendo conduzida por diversas empresas, como, por exemplo, a SLC Agrícola, Agrifirma, Adecoagro, Radar Propriedades Agrícolas, Calys Agro, Vision Brazil Investments, Tiba Agro, Sollus Capital, LG Agro, BrasilAgro, Cantagalo General Grains, Agrinvest e O Telhar Agropecuária Ltda. Adverte-se que a Organização Odebrecht, embora tenha como foco as áreas de engenharia/construção e química/petroquímica, também está atuando no mercado de terras. Mas, antes de apresentar esse processo, é preciso fazer uma leitura geográfica da história da Organização Odebrecht.

\section{Leitura geográfica da história da organização Odebrecht}

A origem da Organização Odebrecht remonta ao século XIX quando o primeiro membro da família chegou ao Brasil seguindo o fluxo da imigração germânica após as frustradas tentativas de unidade nacional no antigo Reino da Prússia ${ }^{5}$. Saindo da Pomerânia, atual estado de Mecklemburgo-Pomerânia Ocidental, o jovem Emil Odebrecht (1835-1912) chegou ao Vale do Itajaí, em Santa Catarina (1856). Em 1859, se naturalizou brasileiro e voltou para a Prússia, onde se diplomou engenheiro na Universidade de Greifswald. Em 1861, retornou para Santa Catarina passando a trabalhar com Hermann Bruno Otto Blumenau (1819-1899) na demarcação de lotes para a construção de uma colônia de imigrantes alemães (ODEBRECHT, 1991; CASTRO, 2003; GONÇALVES, 2003; REVISTA ODEBRECHT INFORMA, 2004).

A presença alemã nas províncias mais meridionais ocorreu a partir de 1824, pois, com a Independência do Brasil (1822), era preciso coibir os ataques argentinos ao sul e dos indígenas no interior. O governo brasileiro, então, resolveu colonizar as matas. Para isso, precisava de um colono que fosse ao mesmo tempo soldado e agricultor, ou melhor, que defendesse e cultivasse a terra nos atuais estados do Rio Grande do Sul, Santa Catarina e Paraná (SANTOS, 1978; WAIBEL, 1979).

A vinda dos colonos de origem germânica antecedeu a promulgação da Lei de $\operatorname{Terras}^{6}(1850)$ e a chegada dos imigrantes italianos (1875), o que lhes permitiu ocupar áreas férteis. As colônias eram fundadas em localidades onde os caminhos de tropa e de 
gado entravam e saiam da selva. A primeira delas foi a de São Leopoldo (1824), ao norte de Porto Alegre, no Vale dos Sinos. Posteriormente, foram criadas as colônias de Rio Negro (1829), que corresponde ao município de mesmo nome entre Paraná e Santa Catarina, e São Pedro de Alcântara (1829) no Vale do Maruim (SANTOS, 1978; WAIBEL, 1979).

Segundo Waibel (1979, p. 237), em 1850, foi fundada a Colônia Blumenau, no Baixo Vale do Itajaí, criada por Hermann Blumenau, sendo que "em 1874, a colônia tinha 7.000 habitantes, todos de origem alemã (...) Em 1882, a colônia possuía 16.000 habitantes, dos quais $71 \%$ eram germânicos". Entre os primeiros moradores da Colônia Blumenau, estava Emil Odebrecht (1835-1912), assim como os seus descendentes.

Como representante da primeira geração da família no Brasil, Emil Odebrecht (1835-1912) notabilizou-se pelos trabalhos de engenharia-agrimensura-cartografia na própria Colônia, seja através da implantação do sistema telegráfico no planalto catarinense ou servindo na Guerra do Paraguai. Casado com Bertha Bichels ${ }^{7}$ (1844-?) tiveram quinze filhos. Estes, como membros da segunda geração da família no Brasil, seguiram por diversos ramos, desde o comércio, produção de cerveja, serviços de agrimensura e topografia (CASTRO, 2003).

É importante destacar a atuação do primogênito da segunda geração, Edmundo Odebrecht (1864-1908). Edmundo almejava se tornar mecânico. Foi para Curitiba estudar o ofício com um amigo do pai. Decepcionado com o mestre, desiste do sonho e se torna comandante de navio. Nessa função, morre em alto-mar numa viagem ao Ceará, deixando esposa e filhos. Dentre os onze filhos do matrimônio de Edmundo com Cecília Altenburg, destaca-se Emílio Odebrecht (1894-1962) (CASTRO, 2003).

A terceira geração da família, representada por Emílio Odebrecht ${ }^{8}$ (1894-1962), participa da introdução da chamada "era do concreto armado" na indústria da construção brasileira, trajetória que o consagraria como "o pioneiro" na narrativa oficial produzida pela Organização Odebrecht (ODEBRECHT, 1991). Emílio participa da construção de importantes obras no Sul, Sudeste e Nordeste do Brasil. Primeiro, foi para o Rio de Janeiro, em 1914. A carência de obras demandadas pelo surto da agroindústria açucareira o levou para a cidade de Recife, em 1917. Atenuada a fase de construções em Pernambuco, muda-se para Salvador, em 1925 (ODEBRECHT, 1991, 2004; GONÇALVES, 2003; REVISTA ODEBRECHT INFORMA, 2004; ORGANIZAÇÃO 
ODEBRECHT, 2015). Na época, a Bahia era um estado atrativo pelas demandas de obras ligadas aos negócios do fumo e do cacau, lavouras que estavam em alta no mercado

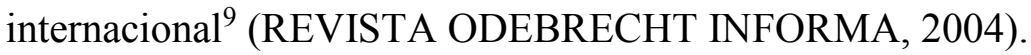

Nessa trajetória de migração e de negócios na construção civil e pesada, Emílio Odebrecht (1894-1962) se casa com Hertha Hinsch e tem três filhos, dentre os quais Norberto Odebrecht (1920-2014). Como representante da quarta geração da família Odebrecht no Brasil, Norberto ingressa no curso de engenharia na então Escola Politécnica de Salvador (1938-1943). Antes de concluir os estudos, assume os negócios da família, pois, em decorrência da Segunda Guerra Mundial (1939-1945), os materiais de construção vindos da Europa tornaram-se caros e escassos, deflagrando uma crise no setor. Com a falência da empresa, em 1941, Emílio Odebrecht retirou-se dos negócios que passam a ser administrados pelo seu filho, Norberto (ODEBRECHT, 1991, 2004; REVISTA ODEBRECHT INFORMA, 2004; ORGANIZAÇÃO ODEBRECHT, 2015).

É importante acrescentar que desde a infância, Norberto Odebrecht aprendeu a conciliar educação e trabalho. Segundo o próprio engenheiro-empresário, sua infância foi marcada por uma rígida educação luterana e uma formação que mesclava conhecimentos teóricos (educação) e práticos (trabalho) (ODEBRECHT, 1991; JACOBINA, 2008).

Ainda criança, tinha aulas particulares com um preceptor luterano (pastor Arnold), no bairro de Nazaré - na época o "mais rico da Bahia" (JACOBINA, 2008). Concomitantemente, frequentava os canteiros de obras na região da Pituba, então periferia da cidade de Salvador formando-se como um "aprendiz de empresário" (ODEBRECHT, 1991, p. 116).

Essa educação familiar destoava das relações que caracterizavam a capital baiana nas primeiras décadas do século XX. De acordo com Norberto Odebrecht, naquela época, a Bahia "era uma autêntica província, e Salvador, uma pequena cidade submetida aos então hegemônicos interesses do mundo rural". A vida social era "regulada por uma pequena elite" de grandes atacadistas, banqueiros e fazendeiros na qual imperava a concepção "de ser o trabalho, sobretudo o trabalho manual, algo degradante". Nesse período, a engenheira, era tratada como uma profissão "pouco nobre, destinada aos estrangeiros ou então aos fillhos de imigrantes e de outras famílias consideradas de 'baixa extração social"” (ODEBRECHT, 1991, p. 87-89; 113). 
Ao assumir os negócios da família, quando tinha 21 anos, o jovem Norberto Odebrecht adaptou os princípios da educação familiar ao mundo empresarial. Para tanto, se baseou naquilo que Harvey (2012, p. 79), chamou de "códigos de honra e de ação" e/ou "redes de confiança entre si". Desse modo, ele construiu uma relação de "parceria" e firmou um "pacto social" com os operários que trabalhavam para seu pai. A estratégia adotada lhe permitiu sanar as dívidas, reerguer o patrimônio e voltar a crescer (ODEBRECHT, 1991; ODEBRECHT S.A., 2013, 2014).

As experiências pessoais, familiares e acadêmicas do engenheiro-empresário serviram para a construção de uma "concepção filosófica" que rege o funcionamento da Organização Odebrecht. Essa "filosofia empresarial”, denominada Tecnologia Empresarial Odebrecht (TEO), difunde para todos os integrantes da corporação um "conjunto de princípios, conceitos e critérios", bem como os "fundamentos éticos, morais e conceituais" que regem a empresa (ODEBRECHT, 1991; ORGANIZAÇÃO ODEBRECHT, 2015).

Além do mais, Norberto Odebrecht considerava-se um "Homem de Sucesso" (ODEBRECHT, 1991, p. 131). Segundo Gonçalves (2003, p. 48; 80), Norberto atribuía seu sucesso empresarial "a um modelo de gestão e de cultura empresarial (TEO) norteada basicamente por sua visão de mundo que está intimamente influenciada pelos valores protestantes recebidos em sua educação familiar". Nesse sentido, os "valores familiares transplantados para o mundo dos negócios" são explorados pelo empresário como um "traço distintivo do Grupo Odebrecht e que lhe confere identidade e o contrasta (com outros grupos econômicos no Brasil)"10.

Fazendo jus à alcunha de "o fundador", tal qual apresentado nos documentos publicados pela Organização Odebrecht, o jovem engenheiro recém-formado cria a empresa "Norberto Odebrecht Construtora Ltda." (1944), posteriormente, transformada na "Construtora Norberto Odebrecht S.A." (1954).

Inicialmente, as obras da Construtora Norberto Odebrecht S.A. (CNO) se limitaram à Bahia. Mas, em menos de uma década, a CNO passou a atuar em outros estados nordestinos. Para isso, o Plano de Metas do governo Juscelino Kubitscheck de Oliveira (1956-1961) foi fundamental ${ }^{11}$. O Plano de Metas (1956-1961), foi um marco na história da engenharia nacional, o que repercutiu sobre a Construtora uma vez que "a 
empresa cresceu e encerrou a década de 50 com a necessidade de se expandir para além dos limites da Bahia" (GONÇALVES, 2003, p. 115).

Outro aspecto favorável para a Organização Odebrecht foi o plano de ação da Superintendência do Desenvolvimento do Nordeste ${ }^{12}$ (SUDENE) (1959-2001). Os incentivos da SUDENE foram fundamentais para que a CNO conquistasse o mercado na região Nordeste, além de permitir, também, que Norberto Odebrecht realizasse investimentos no campo baiano (PRATA, 1994; LIMA, 2017). Segundo Odebrecht (1991, p. 267), a Construtora foi favorecida "através da concessão de incentivos fiscais e outros benefícios a empresas que se instalassem na região [Nordeste] e da criação de um órgão federal específico para o fomento regional: a SUDENE”.

A partir de 1960, as obras de engenharia avançaram para o Sudeste brasileiro. Com a busca de novos clientes, a Construtora Norberto Odebrecht passou a se concentrar "em obras de tecnologia especial" como "emissários submarinos, pontes com fundações profundas, aeroportos, usinas nucleares e siderúrgicas" (ODEBRECHT, 1991, p. 268). Para se dedicar a esse ramo, a empresa precisou investir em pesquisa e desenvolvimento, pois a tecnologia se tornou uma dimensão central dos grandes grupos industriais mundiais, inclusive, como um fator de competitividade cada vez mais importante no plano internacional (CHESNAIS, 1996; GONÇALVES, 2003).

A partir da década de 1970, graças as "suas políticas de reinvestimento e diversificação", a Construtora adquiriu uma abrangência nacional ${ }^{13}$ (1973-1975) (ODEBRECHT, 1991, p. 273). Em 1973, a CNO contava mais de 500 obras a seu crédito. Já no final dos anos 70, a empresa assinou os primeiros contratos de obras fora do país ${ }^{14}$, além de passar a atuar na área química ${ }^{15}$ (ORGANIZAÇÃO ODEBRECHT, 2015).

Na década de 1980, em face desses movimentos, foi criada a holding Odebrecht Sociedade Anônima (S.A.) - lembrando que uma empresa constitui uma holding quando "sua função consiste em deter investimentos ou créditos de outras firmas, no mesmo ou num terceiro país" (CHESNAIS, 1996, p. 56). No caso da Odebrecht S.A., trata-se de uma agregação de empresas ligadas "por laços confederativos"16 (ODEBRECHT, 1991, p. 294). É possível compreender melhor os laços confederativos que enlaçam a Odebrecht S.A. ao saber que

A Odebrecht é uma confederação de pequenas empresas. Cada pequena empresa atua como unidade de negócio, que se relaciona diretamente com o Cliente. Pode ser um contrato de construção, uma unidade industrial ou uma 
concessionária de serviços públicos. A pequena empresa é liderada por um empresário-parceiro e formada por uma equipe concentrada naquela tarefa (...). As pequenas empresas reunidas constituem as grandes empresas ou Negócios. Cada Negócio tem seu Líder Empresarial que, com sua equipe, coordena o conjunto das pequenas empresas que o integram. (ODEBRECHT S.A, 2013 p. 7).

A Organização Odebrecht tem uma concepção específica de gestão que se caracteriza pela "descentralização", "delegação planejada" e a "parceria". Existem os acionistas, os membros da família Odebrecht e os colaboradores. Os acionistas são os investidores, aqueles que permitem, com seus capitais, o desenvolvimento de toda a Organização. Alguns membros da família Odebrecht, seguindo a tendência de uma empresa familiar que se tornou sociedade anônima, assume importantes cargos respeitando a vontade dos acionistas. Já os colaboradores, a depender da posição no nível decisório, tanto podem assumir o posto de "líder" quanto de "liderado". As diretrizes da Organização indicam que os colaboradores se vinculam a uma "estrutura horizontal" na qual as "decisões e os resultados" devem basear-se somente na "satisfação permanente do Acionista e do Cliente" (OBEBRECHT, 1991, p. 247; 251).

Cabe ressaltar, que cada pequena empresa que compõe o Grupo Odebrecht se constitui como um "espaço de formação" para os colaboradores (ODEBRECHT S.A., 2013, p. 7). Ou seja, existe um "Sistema Educacional Odebrecht" (OBEBRECHT, 1991) baseado na conexão de saberes entre pessoas de diferentes gerações ou idades:

a) "jovens de talento" (primeira idade), recém-saídos da educação familiar e que assumem a função "empresarial-operacional";

b) "pessoas amadurecidas" (segunda idade), que ocupam posição de liderança e são responsáveis pelo segmento "estratégico-empresarial";

c) "seres humanos experimentados pela vida" (terceira idade), que detém "sabedoria prática" para transmitir aos demais e assume o papel "político-estratégico" (ODEBRECHT, 1991; REVISTA ODEBRECHT INFORMA, 2004).

A descrição da gestão empresarial da Organização Odebrecht (posição e qualificação dos executivos, denominações nos postos ocupados na empresa, princípios de descentralização e de autonomia) deriva de sua adesão às tendências do discurso empresarial, em voga a partir de 1960 e em curso desde os anos 90. Tais características são inerentes as mudanças do capitalismo, ou, conforme expressão de Boltanski \& 
Chiapello (2009), corresponde a um segundo espírito do capitalismo no qual entra em cena uma transformação da antiga organização (reengineering) com a introdução de novos dispositivos.

Esse tipo de gestão está em consonância com os dispositivos da atual fase do capitalismo mundial, caracterizado pelo desmonte da hierarquia, pela adesão aos princípios de flexibilização, inovação e evolução tecnológica. Os trabalhadores são organizados em equipes pluridisciplinares nas quais o "patrão é o cliente" e a figura do chefe é substituída pela de um "coordenador" e do "líder". Cabe ao "líder", implantar sua visão que, em consonância com o espírito do capitalismo, deve garantir o "engajamento dos trabalhadores sem recorrer à força, mas dando sentido ao trabalho de cada um". Nada é imposto, e é justamente a visão do "líder" que conduz e obtém adesão dos colaboradores mediante "competências", "carisma" e "rede de relações pessoais" (BOLTANSKI \& CHIAPELLO, 2009, p. 104-107).

A trajetória da Organização Odebrecht também está em consonância com o que Chesnais (1996) considerou fundamental para caracterizar os grupos que compõem a estrutura oligopolista no plano mundial. A constituição desse tipo de grupo remete a existência anterior de uma grande empresa no plano nacional, o que implica que ela é resultado de um complexo processo de concentração e centralização do capital que se diversificou antes de começar a se multinacionalizar. Para o economista francês, nesse processo, a ajuda do Estado é um componente indispensável para a competitividade e para a atualização desses grupos em sua forma jurídica contemporânea, a de holding internacional.

O resultado é que, entre 1944 e 2013, a Organização Odebrecht diversificou suas atividades passando a atuar em segmentos distintos, conforme Quadro 1. Nota-se que a Organização Odebrecht realiza atividades em quatro segmentos que são qualificados como negócios, fundos de investimentos, empresas auxiliares e ação social. Cada um desses segmentos tem suas respectivas empresas ${ }^{17}$. Em 2016, o segmento negócios era formado por 14 grandes empresas, dentre as quais estava a $\mathrm{CNO}$, criada na década de 1940. A empresa mais recente era a Odebrecht Latinvest criada, em 2012, com o objetivo de atuar na construção de obras de infraestrutura urbana na América Latina. Por sua vez, o segmento qualificado como fundo de investimento era formado por 3 empresas, criadas em 2012, com atuação no Brasil em outros países da América Latina e da África. 
Quadro 1 - Odebrecht S.A.: negócios, fundos de investimentos, empresas auxiliares e ação social:

\begin{tabular}{|c|c|c|}
\hline Segmento & Instituição/data criação & Função \\
\hline \multirow{14}{*}{ Negócios } & $\begin{array}{ll}\text { Construtora } & \text { Norberto } \\
\text { Odebrecht (1944) } & \end{array}$ & $\begin{array}{l}\text { Atua na construção e nas áreas de transporte e logística, energia, } \\
\text { saneamento, desenvolvimento urbano e edificações }\end{array}$ \\
\hline & $\begin{array}{l}\text { Odebrecht Engenharia \& } \\
\text { Construção Internacional - } \\
\text { América Latina (1997) }\end{array}$ & Cria projetos de engenharia e construção \\
\hline & Braskem (2002) & Produz resinas termoplásticas \\
\hline & $\begin{array}{l}\text { Odebrecht Agroindustrial } \\
(2007)\end{array}$ & $\begin{array}{l}\text { Produz e comercializa etanol, açúcar e energia elétrica originada } \\
\text { da biomassa (Brasil e exterior) }\end{array}$ \\
\hline & Odebrecht Ambiental (2007) & $\begin{array}{l}\text { Promove a universalização dos serviços de água e esgoto e do uso } \\
\text { racional dos recursos naturais }\end{array}$ \\
\hline & Odebrecht Óleo e Gás (2007) & Atua na fase de investimentos e de operações \\
\hline & $\begin{array}{l}\text { Odebrecht Engenharia \& } \\
\text { Construção Internacional - } \\
\text { África, Emirados Árabes e } \\
\text { Portugal (2008) }\end{array}$ & $\begin{array}{l}\text { Atua em serviços de engenharia, saneamento, habitação, energia, } \\
\text { agroindústria e mineração }\end{array}$ \\
\hline & $\begin{array}{l}\text { Odebrecht Engenharia \& } \\
\text { Construção Internacional }- \\
\text { Estados Unidos (2008) }\end{array}$ & $\begin{array}{l}\text { Atua em serviços de engenharia e construção com foco nos } \\
\text { setores de rodovias, pontes, aeroportos, portos e metrôs }\end{array}$ \\
\hline & $\begin{array}{l}\text { Odebrecht Realizações } \\
\text { Imobiliárias (2009) }\end{array}$ & $\begin{array}{l}\text { Cria projetos residenciais, empresariais, comerciais e de uso } \\
\text { misto }\end{array}$ \\
\hline & Odebrecht TransPort (2010) & $\begin{array}{l}\text { Desenvolve e opera serviços de mobilidade urbana, rodovias, } \\
\text { portos, aeroportos e sistemas integrados de logística no Brasil }\end{array}$ \\
\hline & $\begin{array}{l}\text { Odebrecht Engenharia \& } \\
\text { Construção Internacional - } \\
\text { Engenharia Industrial (2010) }\end{array}$ & $\begin{array}{l}\text { Elabora e implanta projetos no exterior para indústrias de base de } \\
\text { diversos setores }\end{array}$ \\
\hline & $\begin{array}{l}\text { Enseada } \\
(2011)\end{array}$ & $\begin{array}{l}\text { Atua na exploração de petróleo em alto-mar e investe na } \\
\text { construção e reforma de estaleiros no Brasil }\end{array}$ \\
\hline & $\begin{array}{l}\text { Odebrecht Defesa e } \\
\text { Tecnologia (2011) }\end{array}$ & $\begin{array}{l}\text { Promove soluções inovadoras e de alta tecnologia para o } \\
\text { desenvolvimento da indústria brasileira de defesa }\end{array}$ \\
\hline & Odebrecht Latinvest (2012) & $\begin{array}{l}\text { Atua no investimento em logística e infraestrutura na América } \\
\text { Latina, voltados para a mobilidade urbana }\end{array}$ \\
\hline \multirow{3}{*}{$\begin{array}{l}\text { Fundos de } \\
\text { Investimentos }\end{array}$} & $\begin{array}{l}\text { Odebrecht África Fund } \\
(2012)\end{array}$ & $\begin{array}{l}\text { Administra investimentos nos setores de varejo, mineração e } \\
\text { energia }\end{array}$ \\
\hline & Odebrecht Latin Fund (2012) & $\begin{array}{l}\text { Administra negócios de infraestrutura na América Latina, } \\
\text { centrada nos segmentos de energia e irrigação }\end{array}$ \\
\hline & $\begin{array}{lll}\text { Fundo } & \text { Odebrecht } & \text { Brasil } \\
(2012) & \end{array}$ & $\begin{array}{l}\text { Administra ativos no setor de energia elétrica e investe em } \\
\text { projetos de engenharia e construção no país }\end{array}$ \\
\hline \multirow{5}{*}{$\begin{array}{l}\text { Empresas } \\
\text { Auxiliares }\end{array}$} & $\begin{array}{l}\text { Odebrecht Corretora de } \\
\text { Seguros (1978) }\end{array}$ & $\begin{array}{l}\text { Protege e promove a segurança empresarial nacional e } \\
\text { internacional }\end{array}$ \\
\hline & $\begin{array}{l}\text { Odebrecht } \\
(1994)\end{array}$ & $\begin{array}{l}\text { Apoia os Integrantes da Organização na construção de um } \\
\text { patrimônio para o período pós-carreira }\end{array}$ \\
\hline & $\begin{array}{l}\text { Odebrecht Comercializadora } \\
\text { de Energia (2012) }\end{array}$ & $\begin{array}{l}\text { Apoia os Negócios da Organização na compra e venda de energia } \\
\text { elétrica no Brasil. }\end{array}$ \\
\hline & $\begin{array}{l}\text { Odebrecht Engenharia de } \\
\text { Projetos (2012) }\end{array}$ & $\begin{array}{l}\text { Desenvolve soluções inovadoras aplicáveis aos diversos estágios } \\
\text { de um empreendimento }\end{array}$ \\
\hline & $\begin{array}{l}\text { Odebrecht Serviços de } \\
\text { Exportação (2013) }\end{array}$ & $\begin{array}{l}\text { Exporta bens e serviços do Brasil, apoia a importação e } \\
\text { exportação dos Negócios }\end{array}$ \\
\hline Ação Social & Fundação Odebrecht (1965) & $\begin{array}{l}\text { Promove educação de jovens para a vida, pelo trabalho e para } \\
\text { valores }\end{array}$ \\
\hline
\end{tabular}

FONTE: Organização Odebrecht (2016).

ELABORAÇÃO: Aline dos Santos Lima. 
Já o segmento empresas auxiliares, abarcava 5 empresas criadas em três contextos espaço-temporais distintos, sem contar a Fundação Odebrecht, responsável pela execução de projetos sociais e, mais recentemente, pela implantação de projetos de geração de trabalho e renda na Bahia (LIMA, 2017).

Ao mesmo tempo em que diversificou os ramos de atuação, a Organização Odebrecht realizou sua expansão geográfica. Esse deslocamento em busca de lucro, faz premente as colocações de Harvey (2005, p. 193), para quem a acumulação do capital sempre foi uma "ocorrência profundamente geográfica. Sem as possibilidades inerentes da expansão geográfica, da reorganização espacial e do desenvolvimento geográfico desigual, o capitalismo, há muito tempo, teria deixado de funcionar como sistema econômico político". Nesse sentido, em 2014, a Organização Odebrecht estava territorializada no Brasil e em outros 35 países, conforme Quadro 2.

Observa-se que até o ano de 2002, a Odebrecht só havia se territorializado por 12 países (34,3\%). Entre 2003-2014, o Grupo avançou para mais 23 países (65,7\%). De qualquer sorte, a geo-história da Organização Odebrecht permite afirmar que, desde suas origens, predomina uma estreita relação entre a empresa e o Estado brasileiro, independentemente da instância e/ou dos governantes que se sucedem no poder. Para Gonçalves (2003), a área de atuação da Odebrecht S.A., tem como critério a geopolítica, ou melhor, tem como base os países e mercados com os quais o Brasil tem uma influência geopolítica significativa, o que demonstra claramente a articulação que se estabelece entre os processos transnacionais realizados pelo Grupo e o Estado-Nação.

Entretanto, por mais contraditório que possa ser, o processo de multinacionalização ${ }^{18}$ dessa corporação está associado ao período em que o Partido dos Trabalhadores (PT) assumiu a presidência do país. Nesse sentido, não é um exagero assegurar quão atuais são as colocações feitas por Marx \& Engels (1980, p. 10), ainda no século XIX, quando diziam que "o governo do estado moderno não é senão um comitê para gerir negócios comuns de toda a classe burguesa". 
Quadro 2 - Territorialização Organização Odebrecht escala mundial (1984-2014):

\begin{tabular}{|c|c|c|c|}
\hline $\mathrm{N}$ & País & Ano & Presidente \\
\hline 1 & Peru & 1979 & Ernesto Geisel (1974-1979) \\
\hline 2 & Angola & 1984 & João Figueiredo (1979-1985) \\
\hline 3 & Argentina & 1987 & \multirow{3}{*}{ José Sarney (1985-1990) } \\
\hline 4 & Equador & 1987 & \\
\hline 5 & Portugal & 1988 & \\
\hline 6 & Alemanha & 1991 & \multirow{3}{*}{ Collor de Mello (1990-1992) } \\
\hline 7 & Estados Unidos & 1991 & \\
\hline 8 & Reino Unido & 1991 & \\
\hline 9 & Colômbia & 1992 & \multirow{3}{*}{ Itamar Franco (1992-1994) } \\
\hline 10 & México & 1992 & \\
\hline 11 & Venezuela & 1992 & \\
\hline 12 & Moçambique & 1997 & FHC (1995-2002) \\
\hline 13 & Emirados Árabes Unidos & 2003 & \multirow{9}{*}{ Lula (2003-2010) } \\
\hline 14 & Bolívia & 2006 & \\
\hline 15 & Djibuti & 2006 & \\
\hline 16 & Panamá & 2006 & \\
\hline 17 & República Dominicana & 2006 & \\
\hline 18 & Libéria & 2007 & \\
\hline 19 & Líbia & 2007 & \\
\hline 20 & Coréia do Sul & 2008 & \\
\hline 21 & Cuba & 2010 & \\
\hline 22 & Áustria & 2011 & \multirow{14}{*}{ Dilma Rousseff (2011-2014) } \\
\hline 23 & Chile & 2011 & \\
\hline 24 & Cingapura & 2011 & \\
\hline 25 & Holanda & 2011 & \\
\hline 26 & Gana & 2012 & \\
\hline 27 & Guatemala & 2012 & \\
\hline 28 & Guiné-Conacri & 2012 & \\
\hline 29 & Paraguai & 2012 & \\
\hline 30 & Uruguai & 2012 & \\
\hline 31 & Guiné Equatorial & 2013 & \\
\hline 32 & África do Sul & 2014 & \\
\hline 33 & China & 2014 & \\
\hline 34 & Espanha & 2014 & \\
\hline 35 & Luxemburgo & 2014 & \\
\hline
\end{tabular}

FONTE: Relatório Anual Odebrecht (2006-2015).

ELABORAÇÃO: Aline dos Santos Lima.

Por outro lado, a territorialização da Organização Odebrecht em 35 países demonstra que a empresa é uma "organização global”, como consta nos Relatórios Anuais da Odebrecht S.A. (ODEBRECHT S.A., 2012-2017). Essa expansão se caracteriza como “produto necessário para o processo de acumulação" (HARVEY, 2005, p. 48), pois, na fase atual da mundialização do capital, o futuro dos oligopólios nacionais depende de sua capacidade de manejar a rivalidade num contexto mundial (CHESNAIS, 1996). É 
possível ratificar a abrangência global da Organização Odebrecht, dentre outros, na distribuição espacial de seus colaboradores, conforme Quadro 3.

Quadro 3 - Número "colaboradores" da Odebrecht S.A. no Brasil e no exterior (20022017):

\begin{tabular}{|r|r|r|r|}
\hline \multirow{2}{*}{ Ano } & \multicolumn{3}{|c|}{ Colaboradores* } \\
\cline { 2 - 4 } & Brasil & Exterior & Total \\
\hline 2002 & 21.566 & 7.040 & 28.606 \\
\hline 2003 & 18.644 & 6.250 & 24.894 \\
\hline 2004 & 19.265 & 6.259 & 25.524 \\
\hline 2005 & 22.498 & 9.145 & 31.643 \\
\hline 2006 & 18.823 & 16.389 & 35.212 \\
\hline 2007 & 34.129 & 24.867 & 58.996 \\
\hline 2008 & 36.453 & 45.706 & 82.159 \\
\hline 2009 & 45.061 & 42.601 & 87.662 \\
\hline 2010 & 78.569 & 40.248 & 118.817 \\
\hline 2011 & 111.045 & 134.595 & 245.640 \\
\hline 2012 & 127.166 & 47.865 & 175.031 \\
\hline 2013 & 118.108 & 63.448 & 181.556 \\
\hline 2014 & 106.087 & 62.062 & 168.149 \\
\hline 2015 & 77.983 & 50.503 & 128.486 \\
\hline 2016 & 47.469 & 32.147 & 79.616 \\
\hline 2017 & 38.871 & 18.718 & 57.589 \\
\hline
\end{tabular}

* Exceto os terceirizados.

FONTE: Odebrecht S.A. (2002-2018).

ELABORAÇÃO: Aline dos Santos Lima.

Como já foi pontuado, a trajetória da Organização Odebrecht esteve atrelada, inicialmente, a construção de obras em médias e grandes cidades ${ }^{19}$. Ao longo dos anos, a Organização se consolidou, expandiu e diversificou seus investimentos. De acordo com os indicadores econômico-financeiros da Organização, os negócios mais rentáveis estão concentrados na área "química e petroquímica" seguida pela "engenharia e construção", conforme Quadro 4. Mas, a corporação tem operado, também, em fundos de pensão e fundos de investimentos ${ }^{20}$.

Com base em Chesnais (1996, p. 275), é possível deduzir que a Organização Odebrecht vem realizando uma "imbricação entre as dimensões produtiva e financeira da mundialização do capital" como "elemento inerente ao seu funcionamento cotidiano". Ou seja, a empresa enquadra-se nas novas formas de centralização do capital sob o jugo dos fundos de investimentos, fundos mútuos e fundos de pensão. 
Quadro 4 - Comparação da receita bruta das áreas de "engenharia e construção" e "química e petroquímica" com a receita bruta total da Organização Odebrecht, 2001-

2017:

\begin{tabular}{|c|c|c|c|c|c|}
\hline Ano & $\begin{array}{c}\text { Total receita } \\
\text { bruta } \\
\text { Organização } \\
\text { Odebrecht } \\
\text { (R\$ milhões) }\end{array}$ & $\begin{array}{c}\text { Receita bruta } \\
\text { engenharia e } \\
\text { construção (R\$ } \\
\text { milhões) } \\
\text { (1) }\end{array}$ & $\begin{array}{l}\text { Receita bruta } \\
\text { química e } \\
\text { petroquímica } \\
\text { (R\$ milhões) } \\
\text { (2) }\end{array}$ & $\begin{array}{c}\text { Receita bruta } \\
1+2 \\
\text { (R\$ milhões) }\end{array}$ & $\begin{array}{l}\text { Percentual } 1+2 \mathrm{em} \\
\text { relação ao total da } \\
\text { receita bruta da } \\
\text { Organização } \\
\text { Odebrecht }\end{array}$ \\
\hline 2001 & 8.349 & -- & -- & -- & -- \\
\hline 2002 & 13.241 & 4.326 & 8.701 & 13.027 & $98,38 \%$ \\
\hline 2003 & 17.336 & 4.552 & 12.545 & 17.097 & $98,62 \%$ \\
\hline 2004 & 21.829 & 5.850 & 15.955 & 21.805 & $99,89 \%$ \\
\hline 2005 & 23.437 & 6.394 & 17.043 & 23.437 & $100,0 \%$ \\
\hline 2006 & 24.031 & 7.425 & 16.545 & 23.970 & $99,7 \%$ \\
\hline 2007 & 31.406 & 8.867 & 22.463 & 31.330 & $99,75 \%$ \\
\hline 2008 & 40.954 & 16.925 & 23.020 & 39.945 & $97,53 \%$ \\
\hline 2009 & 40.640 & 18.721 & 19.466 & 38.187 & $93,96 \%$ \\
\hline 2010 & 53.860 & 16.663 & 31.547 & 48.210 & $89,50 \%$ \\
\hline 2011 & 71.009 & 22.200 & 39.816 & 62.016 & $87,33 \%$ \\
\hline 2012 & 84.431 & 29.229 & 42.114 & 71.343 & $84,49 \%$ \\
\hline 2013 & 96.930 & 32.928 & 47.770 & 80.698 & $83,25 \%$ \\
\hline 2014 & $107.679 *$ & 33.140 & 53.082 & 86.222 & $80,07 \%$ \\
\hline 2015 & $132,5^{* *}$ & -- & -- & -- & -- \\
\hline 2016 & 89.762 & -- & -- & -- & -- \\
\hline 2017 & 82.000 & -- & -- & -- & -- \\
\hline
\end{tabular}

* Existem divergências nos montantes referentes a receita bruta da Organização Odebrecht. Enquanto o relatório anual indica que o valores se refere a milhões de reais um release na página eletrônica da Organização informa que se trata de uma receita bruta equivalente a bilhões de reais. Em novembro de 2016, foi encaminhada uma mensagem eletrônica para três funcionárias do setor de Comunicação Corporativa da Odebrecht questionando a divergência. Porém, não obtivemos resposta.

** Receita em bilhões de reais no relatório.

FONTE: Odebrecht S.A., (2002-2018).

ELABORAÇÃO: Aline dos Santos Lima.

A esfera financeira tem representado o posto avançado do movimento de mundialização do capital. Essa situação é possível graças às condições que permitiram ao capital concentrado atuar praticamente a seu bel-prazer, com poucos controles ou freios. Contribuiu para isso a morosidade dos governos no sentido de criar um conjunto de regras enquadrando a atividade financeira e estabelecendo estrito controle sobre ela. A liberdade alcançada pelo movimento da mundialização financeira permitiu que se forjasse uma concepção das finanças como indústria (CHESNAIS, 1996).

Esse tipo de reflexão pode levar a interpretações como aquela que atribui ao capital monetário uma capacidade intrínseca de valorização autônoma. Ou seja, na 
medida em que a esfera financeira é um dos campos de valorização do capital ela deve gerar lucros como em qualquer outro setor. Mas, em concordância com François Chesnais, é na esfera da produção onde são criados o valor e os rendimentos fundamentais, pois, a "esfera financeira alimenta-se da riqueza criada pelo investimento e pela mobilização de uma força de trabalho de múltiplos níveis de qualificação. Ela mesma não cria nada" (CHESNAIS, 1996, p. 241).

A abrangência dos negócios da Odebrecht em fundos de pensão (previdência complementar) e fundos de investimentos se apoia, também, no que Luc Boltanski e Éve Chiapello tratam sobre o estágio em que se encontra o capitalismo. Estes sociólogos franceses defendem a ideia de um capitalismo regenerado pari passu a uma situação social degenerada. Contrariando a ideia de uma "crise" do capitalismo desde 1973, os autores asseguram que, na verdade, há um capitalismo florescente. Embora o crescimento tenha se mantido desacelerado, os rendimentos do capital se elevaram. Houve muitos ganhos para as multinacionais com a reestruturação do capitalismo mundial, ou seja, com a possibilidade de fazer o capital frutificar por meio do investimento, da aplicação econômica e das fusões e aquisições realizadas no mundo inteiro. Tomando o Grupo Odebrecht como exemplo, nota-se a possibilidade de lucros puramente especulativos através daquilo que Boltanski \& Chiapello (2009, p. 20-22) chamam como "desregulamentação dos mercados financeiros" e criação de "novos produtos financeiros".

Cabe salientar que, as informações problematizadas e os dados expostos e sistematizados nos Quadros 2, 3 e 4, passaram por mudanças significativas a partir de 2015. Em 2015-2016, a presença da Organização na escala global variou entre 26 e 25 países, respectivamente. Mas, em 2017, a territorialização do grupo decresceu para 14 países (ODEBRECHT S.A., 2016-2018). Esse processo se reflete, também, na queda sucessiva no número de "colaboradores"21 e na receita bruta da Organização (ODEBRECHT S.A., 2002-2018).

Esse contexto está relacionado aos escândalos de corrupção revelados com a prisão de Marcelo Bahia Odebrecht, então diretor-presidente da Odebrecht S.A., (20082015). A prisão, na $14^{\circ}$ fase da "Operação Lava Jato", chamada de "Erga Omnes" (19/06/2015), ocorreu sob a acusação de pagamentos de propina com o objetivo de obter vantagens em contratos com a estatal Petrobras, sem contar o esquema de contabilidade 
paralela para garantir benefícios indevidas a terceiros, expostas através da $26^{\circ}$ fase da “operação" intitulada como "Xepa"22 (22/03/2016) (POLÍCIA FEDERAL, 2016).

Cumpre salientar que, em meio à diversidade de setores, a internacionalização em pouco mais de três dezenas de países de quatro continentes e a receita gerada, a Organização Odebrecht demonstrou interesse pelo espaço rural desde suas origens (LIMA, 2017). O diferencial é a forma como o conteúdo rural foi sendo apropriado por essa fração do capital.

Essa hipótese pode soar anacrônica diante de um contexto que - como diria Chesnais (1996 p. 244-245), ao comparar o crescimento dos fluxos comerciais em determinados países - "comporta transferências efetivas de riqueza para a esfera financeira". Mas, o fato é que a consolidação como "homem de sucesso" e "empresário autêntico" (ODEBRECHT, 1991, p. 131) levaram Norberto Odebrecht a investir, também, no campo. Nesse caso, investir no campo significa tanto imobilizar capital na aquisição de terras como incursionar na esfera da produção. Mas, essa empreita também tem outros significados. Pois, o capital deseja "absoluta liberdade de movimento e que todos os campos da vida social, sem exceção, sejam submetidos à valorização do capital privado" (CHESNAIS, 1996, p. 25).

As intervenções do Grupo Odebrecht no espaço rural são de duas ordens. Ora como projetos educacionais e de geração de trabalho e renda que almejam o lucro, mas resguarda outras intencionalidades como o marketing e a ação social sob a alçada da Fundação Odebrecht (LIMA, 2017). Ora se efetiva na forma de uma típica empresa capitalista cujo objetivo é somente o lucro sob a alçada da holding Odebrecht S.A. Os exemplos mais ilustrativos desse último caso são a Atvos (2007) e a Odebrecht Terras S.A. (2010), não obstante as experiências nas fazendas "Agrícola Contendas S.A." e “Agrícola Seringalista da Bahia S.A.”, na década de 1940-50, na região conhecida como Baixo Sul no estado da Bahia (LIMA, 2017).

\section{Organização Odebrecht, entre o capitalismo florescente e sua crise estrutural}

Dentre as (cerca de) cinco centenas de pequenas empresas que compõem a holding Odebrecht S.A. (ODEBRECHT S.A, 2013), destaca-se duas que tem atuação direta no espaço rural brasileiro, a Atvos (2007) e a Odebrecht Terras S.A. (2010). Ambas resultam 
do processo de concentração e centralização do capital de uma grande empresa nacional que se mundializou com a ajuda do Estado (CHESNAIS, 1996). Ao mesmo tempo, elas foram criadas seguindo "concepções filosóficas" que agregam todos os elementos inerentes ao espírito do capitalismo (reengineering) (BOLTANSKI \& CHIAPELLO, 2009). Mas, principalmente, essas duas empresas são exemplos sui generis do trancafiamento da natureza (MITIDIERO JÚNIOR, 2016) em suas diversas expressões.

A Atvos foi criada, em dezembro de 2017, a partir de uma reestruturação da Odebrecht Agroindustrial, originalmente fundada em 2007. Supõe-se que essa mudança tenha sido uma estratégia para minimizar os efeitos dos escândalos de corrupção envolvendo a Organização Odebrecht (LIMA, 2017). Apesar de inúmeras evidencias nesse sentido, o discurso oficial difunde que "Em 2017, ao completar 10 anos e com o objetivo de renovar seu compromisso com a construção de um futuro sustentável, a Odebrecht Agroindustrial anunciou a mudança de sua marca para Atvos" (ORGANIZAÇÃO ODEBRECHT, 2018).

Desde julho de 2007, a empresa, hoje conhecida como Atvos, atua na produção e comercialização de etanol e açúcar, além de energia elétrica oriunda de biomassa. Os negócios em torno do setor sucroenergético pela Odebrecht está presente em nove unidades agroindustriais ${ }^{23}$ criadas, entre 2008-2011, nos estados de Goiás, Mato Grosso, Mato Grosso do Sul e São Paulo (ATVOS, 2018).

A extensão territorial das propriedades onde a cana da Atvos é plantada, abarca "131,6 mil hectares de cultivo contratados com parceiros agrícolas". Toda produção (plantio, cultivo e colheita) ocorre de forma, totalmente, mecanizada, não obstante a empresa possua 11.121 integrantes ocupados em empregos diretos (ODEBRECHT AGROINDUSTRIAL, 2017, p. 12-13).

A partir dessas informações, e da pesquisa em fontes secundárias, deduz-se que a Atvos promove, no campo brasileiro, o mecanismo de territorialização do capital monopolista na agricultura, seja em terra própria ou via arrendamento com os parceiros agrícolas. Vale lembrar que, onde o capital se territorializa

Ele varre do campo os trabalhadores, concentrando-os nas cidades, quer para serem trabalhadores para a indústria, comércio ou serviços, quer para serem trabalhadores assalariados no campo (bóias-frias). Neste caso, o processo especificamente capitalista se instala, a reprodução ampliada do capital desenvolve-se na sua plenitude (OLIVEIRA, 1995, p. 284). 
Em 2013, a Odebrecht Agroindustrial encerrou a safra com 100 mil hectares de cana-de-açúcar, o que possibilitou uma exportação de 458 mil toneladas de açúcar para trinta países e a exportação de $96,6 \mathrm{mil} \mathrm{m}^{3}$ de etanol para seis países. Tudo isso gerou uma receita bruta no valor de R\$2.824 milhões (ODEBRECHT S.A., 2014, p. 72-73). Já em 2014, a Odebrecht Agroindustrial exportou 517,5 mil toneladas de açúcar para 24 países e 33,3 mil $\mathrm{m}^{3}$ de etanol para um único país, a Coréia do Sul, o que gerou uma receita bruta no valor de R 3.328 milhões (ODEBRECHT S.A., 2015, p. 66-67). Apesar desse crescimento, o jornal "Correio do Estado", da cidade de Campo Grande, no Mato Grosso do Sul, veiculou, em março de 2015, uma notícia sobre o atraso de pagamento pela parceria agrícola de 80 mil hectares de terras arrendadas por 50 produtores rurais para a Odebrecht Agroindustrial (USINA DA ODEBRECTH..., 2015).

No mesmo ano em que a Atvos é fundada, em 2007, são criadas as primeiras empresas que atuam no mercado de terras no Brasil. Esse processo tem início com a abertura do capital da SLC Agrícola e com a criação de sua empresa especializada na comercialização de terras, a LandCo (OLIVEIRA, 2012).

Para Mitidiero Júnior (2016, p. 17-19), o avanço do capital sobre a natureza (especialmente nas áreas rurais), é reflexo da crise do capital global. Para o autor, desde 2008, a crise do mercado norte-americano "alastra-se como um efeito dominó (...) o capital aplicado na esfera financeira quase cessa suas possibilidades de reprodução ampliada". Uma das consequências dessa crise seria a compra de terras ou, como diz o autor, "a apropriação da natureza de forma privada e mercadológica pode ser um dos refúgios (...) para esse capital sem possibilidades de lucro em outras esferas do econômico".

Nesse bojo, em maio de 2010, na cidade de São Paulo, foi criada a Odebrecht Terras S.A. Sua primeira razão social foi “Hattiesburg Participações Ltda.” E, na ocasião, seu objetivo social era "de participação em outras sociedades como sócia, acionista, quotista e administração de bens, e a representação de sociedades nacionais e estrangeiras por conta própria ou de terceiros". Em março de 2011, a "companhia alterou sua razão social para ETH Bioeletricidade S.A., passando de sociedade limitada para sociedade anônima". Em janeiro de 2015, a companhia alterou sua razão social para Odebrecht Terras S.A., bem como seu objetivo social, que é atuar como intermediária, ou seja, 
"parceira" da Odebrecht Agroindustrial nos arrendamentos de terras (SÃO PAULO, 2015).

Segundo o Relatório Anual da Odebrecht Agroindustrial Safra 2014/2015, a Odebrecht Terras S.A., era "uma diretoria da Odebrecht Agroindustrial". Ao se tornar uma empresa, a Odebrecht Terras S.A., ficou "responsável pelo melhor aproveitamento das fazendas mantidas pela Odebrecht Agroindustrial, trazendo segurança empresarial ao Negócio por meio de aquisição de terras para plantio de cana e ampliação do volume adquirido de Fornecedores. Também está sob seu escopo gerir as áreas de Reservas Legal e Áreas de Proteção Permanente (APPs), além de buscar novos parceiros" (ODEBRECHT AGROINDUSTRIAL, 2015, p. 26).

Entretanto, a Odebrecht Terras S.A., não atua apenas em parceria com a recémcriada Atvos. De acordo com as informações que compõem as demonstrações financeiras da Odebrecht Terras S.A., a companhia mudou o objetivo social em 2015. Desde então, atua na aquisição, venda e operação de terras próprias e de terceiros; parceria rural ou arrendamento com terras próprias e de terceiros; fornecimento de cana de açúcar; plantio e comercialização de culturas anuais e perenes para produção de grãos e/ou produção de biomassa; plantio de florestas e transformação de eucalipto e desdobramento da madeira; produção de mudas e outras formas de propagação vegetal; celebração de atos de comércio decorrentes dessas atividades; prestação de serviços e aluguéis de máquinas e equipamentos agrícolas para operação e monitoramento da agricultura em geral; transportes e armazenamento das produções agrícolas e produtos acabados; serviços de consultoria, assessoria e operações agrícola e florestal; agenciamento, comercialização e aluguel de servidão de reservas florestais; produção e comercialização de biodiesel e outros combustíveis alternativos; transformação de grãos em óleos e rações; e outras atividades agropecuárias conexas e correlatas (SÃO PAULO, 2015).

\section{Considerações finais}

A leitura geográfica da história da Organização Odebrecht permite concluir que a empresa (e seu fundador) se apropriou dos códigos e das redes de confiança dos trabalhadores, bem como investiu em pesquisa e desenvolvimento contando sempre com a ajuda do Estado. Esses elementos foram sendo apropriados independentemente da 
concepção em voga, seja a compreensão de um capitalismo florescente (BOLTANSKI \& CHIAPELLO, 2009) ou de crise estrutural (MITIDIERO JÚNIOR, 2016).

Importa evidenciar que, apesar da aderência aos dispositivos de uma gestão empresarial eficiente, flexível e atenta as novas tecnologias, o acesso à terra sempre esteve na rota dos projetos pessoais e empresariais de Norberto Odebrecht. Por fim, a relação da família Odebrecht, especialmente a partir da quarta geração, com a terra sempre esteve pautada na lógica do capital, ou seja, independentemente da escala espaço-temporal de suas ações a reprodução do capital era a finalidade. Cumpre salientar a importância de estudos que busquem compreender como a Organização Odebrecht tem tratado a questão agrária em seus negócios, especialmente a partir dos escândalos de corrupção e, principalmente, após a morte do fundador da corporação, o engenheiro-empresário Norberto Odebrecht, em 2014.

\section{Notas}

\footnotetext{
${ }^{1}$ Parte das pesquisas realizadas para a construção desse texto, entre 08/2013 e 02/2017, foi financiada com recursos oriundos da Seleção de candidatos a bolsa de Doutorado FAPESB/IF Baiano, através da Chamada Interna PROPES n. 05/2013.

${ }^{2}$ É importante esclarecer que a proposição de uma geografia histórica foi pensada por Antonio Carlos Robert Moares com a intenção de contribuir geograficamnete com o conhecimento da formação social brasileira, ou seja, a partir do objetivo maior de "fortalecer e sedimentar" a construção do "entendimento da geografia como uma modalidade de abordagem histórica, dedicada à análise dos processos sociais e de formação dos territórios. Isto é, a visão da geografia humana como uma história territorial" (MORAES, 2000, p. 11).

${ }^{3}$ Para Santos (2002 [1978], p. 149), a análise "é uma violência raciocinada, indispensável para ultrapassar o nível das operações puramente descritivas, incompatíveis como o conhecimento dos fatos dinâmicos, das coisas que têm vida".

${ }^{4} \mathrm{O}$ processo de monopolização do território pelo capital monopolista "cria, recria, redefine relações de produção camponesa. Ele abre espaço para que a produção camponesa se desenvolva e com ela o campesinato como classe social. O campo continua povoado, a população rural pode até se expandir. Neste caso o desenvolvimento do campo pode possibilitar, simultaneamente, a distribuição da riqueza na área rural e nas cidades, que nem sempre são grandes. Neste caso, ainda, o próprio capital cria as condições para que os camponeses produzam matérias-primas para as indústrias capitalistas, ou mesmo viabilizem o consumo dos produtos industriais no campo (ração para a avicultura ou na suinocultura). Esse processo revela que o capital sujeitou a renda da terra produzida pelos camponeses à sua lógica, ou seja, estamos diante da metamorfose da renda da terra em capital. O que este processo revela, portanto, é que estamos diante do processo de produção do capital, que nunca é produzido por relações especificamente capitalistas" (OLIVEIRA, 1995, p. 284).

${ }^{5}$ Genealogia da família Odebrecht, Anexo A.

${ }^{6}$ É importante reforçar que a expropriação da terra constitui a base de todo processo da produção capitalista (MARX, 2013). No Brasil, esse processo de expropriação tem como marco a Lei $n^{\circ} .601$ de 18 de setembro de 1850, conhecida como Lei de Terras. Criada pela elite política, que também era a elite rural, a operacionalização dessa Lei significava que a terra não estaria mais livre para ser ocupada, mas livre para ser mercantilizada entre os que tivessem condições, o que permitiria a renda capitalista (MARTINS, 1979; GERMANI, 1993, 2005).
} 
${ }^{7}$ Segundo Castro (2003), Bertha Bichels nasceu em Hamburgo, em 1844. Veio para o Brasil, com apenas 13 anos, com sua família após um incêndio que destruiu a fábrica de laticínios de seu pai, em 1842.

${ }^{8}$ Em 1920, Emílio Odebrecht (1894-1962) se torna sócio da construtora "Isaac Gondin e Odebrecht Ltda." Em 1923, a construtora foi transformada em "Emílio Odebrecht \& Cia.", na qual Emílio se tornou o principal sócio-proprietário. Segundo a narrativa oficial, a "Emílio Odebrecht \& Cia", era uma das construtoras mais ativas da Bahia e do Nordeste realizando várias edificações no período entre guerras (ODEBRECHT, 1991, 2004; REVISTA ODEBRECHT INFORMA, 2004).

${ }^{9}$ De acordo com Rômulo Barreto de Almeida, o fumo era "elemento certo, constante, e de todos os tempos, desde os coloniais, cultura que era uma das mais valiosas desta Província”. Segundo o economista, a produção fumageira passou por várias oscilações. Um período de queda pode ser associado à redução/fim do tráfico negreiro, que usava o fumo como pagamento dos escravos; a Independência, e a consequente perda de preferência dos gêneros coloniais por Portugal; e aos reflexos de uma doença que acometeu o rebanho e comprometeu a oferta do exterco necessário a lavoura. A situação do fumo melhora com a criação de fábricas de rapé, de charutos e de cigarros e, especialmente, com a guerra de Secessão nos Estados Unidos e com a independência de Cuba, conflitos que favoreceram nossa exportação. Logo, "O consumo mundial se ampliou. E as peculiaridades dos fumos bahianos contribuíram para manter a preferência de muitos fumantes. E assim, ampliado o consumo interno, e restaurado o mercado mundial, depois de longo processo e várias peripécias, chegou o fumo no final do século a ser o nosso principal produto de exportação, atingindo em 1902 a sua maior exportação" (ALMEIDA, 2009 [1952], p. 89-90). Em relação ao cacau, Almeida (2009 [1952], p. 90-91), afirma que essa lavoura "surgiu aos poucos, tomando vulto depois de 1890. E foi providencial. Abriu uma nova fase em nossa economia (...). A exportação do cacáu só em 1838-39 superou 1.000 sacas (1.322) (...). Em 1893 se registrou uma exportação superior a 100.000 sacas. Em 1911 superou a 500.000 sacas. A Bahia sucedeu ao Equador em 1905 como maior produtor mundial competindo com S. Tomé".

${ }^{10}$ Essa análise pode ser observada tanto nas páginas eletrônicas vinculadas à Organização, nos relatórios anuais da holding Odebrecht S.A. (ODEBRECHT S.A., 2002-2015) e das empresas que estão ligadas a mesma, assim como nas várias obras publicadas pelo próprio engenheiro-empresário, como, por exemplo: "De que necessitamos" (1968), "O Essencial em Pontos de Referência" (1970), "Pontos de Referência" (1970), "Sobreviver, Crescer e Perpetuar" (1983), "Influenciar e Ser Influenciado" (1984) e "Educação pelo Trabalho" (1991).

${ }^{11}$ Para Lafer (1987, p. 30), o Plano de Metas é "considerado como a primeira experiência efetivamente posta em prática de planejamento governamental no Brasil", tanto pela "complexidade de suas formulações" quanto pela "profundidade de seu impacto". Ainda segundo o professor da Faculdade de Direito da Uuniversidade de São Paulo, o Plano direcionou recursos para investimentos em cinco setores: energia, transporte, alimentação, indústria de base e educação. Três setores concentravam $93,4 \%$ do montante através da construção de obras para elevação da capacidade instalada de energia elétrica, formação do programa nacional de energia nuclear, produção de carvão, produção e refinação de petróleo (setor de energia); reaparelhamento e construção de ferrovias, pavimentação e construção de rodovias, serviços portuários e de dragagem, incorporação da marinha mercante e establecimento da indústria aeronáutica (setor de transportes); expansão das indústrias siderúrgica, automobilística, de construção naval e mecânica, aumento da produção de alumínio, metais não-ferrosos, cimento, celulose/papel e borraha e exportação de minérios de ferro (setor de indústrias de base).

${ }^{12}$ Barros (1987, p. 119), ao analisar duas experiências de planejamento regional no Brasil, uma no Nordeste e outra no estado de São Paulo, afirma que a criação da SUDENE mudou o "enfoque sobre a problemática da seca do Nordeste". Para o autor, "desde 1877 o governo federal executava programas de combate à seca" pautados no planejamento e na execução de obras de engenharia que procuravam "incrementar a oferta de água no Polígono da Seca", política que, segundo ele, era denominada por Celso Furtado como 'approach hidráulico'. A proposta da SUDENE era de uma "nova estratégia". Nesse sentido, a "solução do problema não estaria na oferta de água, mas sim num conjunto mais amplo de medidas que assegurassem o desenvolvimento econômico da região como um todo".

${ }^{13} \mathrm{O}$ processo de espacialização da Construtora pelo país, pode ser observado a partir das seguintes obras: na Bahia, através do Círculo Operário (1946); Estaleiro Fluvial da Ilha do Fogo (1947); cais e a ponte de atracação em Canavieiras (1948); porto de Ituberá (1949); Usina Hidrelétrica de Correntina (1952); acampamento do projeto Oleoduto Catu-Candeias da Petrobrás (1953); Teatro Castro Alves (1958) e sua reconstrução após incêndio (1967). Em Pernambuco, as fábricas da Willys Overland; Coperbo; Alpargatas Confecções; e das Tintas Coral do Nordeste (a partir de 1963). Na região Sudeste, o edifício-sede da Petrobrás (1969); o campus da Universidade Federal do Rio de Janeiro (1969); o Aeroporto Internacional

CAMPO-TERRITÓRIO: revista de geografia agrária, v. 13, n. 30, p. 187-217, ago., 2000 
do Galeão (1969); e a Usina Termonuclear Angra I (1969). Em nível nacional, a Ponte Colombo Salles, em Florianópolis (1973); a restauração do Teatro Amazonas em Manaus (1973). Mais recentemente, em 2008, participou da construção da Usina Hidrelétrica Santo Antônio (Rondônia). Em 2013, participou da reforma das arenas Fonte Nova (Salvador), Pernambuco (Recife) e Estádio do Maracanã (Rio de Janeiro) (REVISTA ODEBRECHT INFORMA, 2004; ORGANIZAÇÃO ODEBRECHT, 2015).

${ }^{14}$ Os primeiros contratos da Construtora Norberto Odebrecht fora do país foram as obras de desvio do Rio Mau Le, para a Hidrelétrica Colbún Machicura no Chile, e das obras para a Hidrelétrica Charcani V, no Peru (ORGANIZAÇÃO ODEBRECHT, 2015).

${ }^{15}$ Em 1979, a Organização Odebrecht passa a atuar na área química. Data da mesma época, a convite da Petrobras, seu ingresso na área de perfuração de petróleo através da "Odebrecht Perfurações Ltda." (ODEBRECHT, 1991, p. 273). Ainda na década de 1970, a Organização adquiriu parte do capital da "Companhia Petroquímica Camaçari” na Bahia (ORGANIZAÇÃO ODEBRECHT, 2015).

${ }^{16}$ É importante acrescentar que todas as empresas que compõem a Organização Odebrecht são controladas por uma "holding familiar", a "Kieppe Patrimonial". Essa "holding familiar", além de controlar a Odebrecht S.A., realiza a mesma função à frente da Presidência de Honra da Odebrecht S.A., da Presidência do Conselho Curador da Fundação Odebrecht e assume a liderança da Fazenda Reunidas Vale do Juliana (ODEBRECHT, 2004, p. 6).

${ }^{17}$ Em 2013, havia "cerca de 500 pequenas empresas na Organização Odebrecht, que se distribuem em 15 Negócios" (ODEBRECHT S.A, 2013 p. 7).

${ }^{18}$ Para Oliveira (2012, p. 5), a multinacionalização compreende o "processo de transformação das empresas nacionais em empresas internacionais e multinacionais através da expansão por diferentes países via abertura de filiais, aquisições, fusões, associações etc".

${ }^{19}$ Até março de 2015, a trajetória de 70 anos da Odebrecht no setor de engenharia e construção no Brasil e no exterior podia ser evidenciada nos seguintes números: 83 usinas hidrelétricas; 17 usinas térmicas; 2 usinas nucleares; 75 linhas de transmissão compreendendo $5.728 \mathrm{~km}$ de extensão; 750 obras de edificações; 311 rodovias totalizando $13.495 \mathrm{~km}$ de extensão; 1.505 pontes e viadutos; 367 tuneis; 23 linhas de metrôs e trens urbanos; 34 ferrovias somando $2.781 \mathrm{~km} ; 41$ aeroportos; 52 portos; 439 obras industriais; 73 estruturas offshore para plataformas; 19 obras de gasodutos e oleodutos; 200 estações de tratamento, bombeamento e elevatórias; 174 obras de tubulações para saneamento que somam $4.980 \mathrm{~km} ; 36$ projetos de irrigação; e três linhas de teleférico (ORGANIZAÇÃO ODEBRECHT, 2015).

${ }^{20}$ No âmbito do Grupo Odebrecht, o primeiro fundo de pensão foi criado, em 1994, através da "Odeprev Odebrecht Previdência" cujo funcionamento se deu a partir de julho de 1995 (BRASIL, 1994; ODEBRECHT S.A., 2005). Trata-se de um plano de previdência complementar para os integrantes da Organização instituído pela Odebrecht S.A. e aprovado pelo então "Ministério da Previdência Social" (BRASIL, 1994). Vale lembrar que, para François Chesnais, os fundos de pensão são qualificados como “ninhos de acumulação de lucros financeiros” cujos administradores personificam o 'novo capitalismo' de fins do século XX obcecados pela rentabilidade e liquidez (CHESNAIS 1996, p. 246).

Os fundos que administram investimentos, por sua vez foram criados em 2012, e tem atuação na América Latina, África e no Brasil em diversos setores (ORGANIZAÇÃO ODEBRECHT, 2016). Segundo o Banco Central, um fundo de investimento compreende "uma comunhão de recursos, constituída sob forma de condomínio, destinado à aplicação em ativos financeiros no mercado financeiro e de capitais. $\mathrm{O}$ valor da cota do fundo de investimento é recalculado periodicamente. A remuneração varia de acordo com os rendimentos dos ativos financeiros que compõem o fundo. Não há, geralmente, garantia de que o valor resgatado será superior ao valor aplicado. Todas as características de um fundo devem constar de seu regulamento. $\mathrm{O}$ funcionamento dos fundos de investimento depende de prévia autorização da Comissão de Valores Mobiliários" (BANCO CENTRAL DO BRASIL, 2016).

${ }^{21}$ Em 2016, "comparativamente a 2015, a Odebrecht apresentou redução do número de integrantes (...) A taxa de rotatividade é de 12,6\%" (ODEBRECHT S.A., 2017, p. 49), sendo que "no final de 2017, o Grupo Odebrecht era formado por aproximadamente 58 mil integrantes, uma redução de $38 \%$ em relação ao ano anterior" (ODEBRECHT S.A., 2018, p.72).

${ }^{22}$ Os escandâlos envovlendo a Organização Odebrecht são reconhecidos por Emílio Alves Odenbrecht, então Presidente do Conselho de Administração da Odebrecht S.A. e pai de Marcelo Bahia Odebrecht, na mesnagem insitulada "Aprender com os erros e evoluir com o Brasil. O texto aborda o seguinte: "O ano de 2015 foi crítico para a Organização Odebrecht (...) vivenciamos uma crise institucional sem paralelo em nossa história, cujas razões são de conhecimento público (...) É preciso reconhecer, entretanto, que estávamos vulneráveis, e isso ficou evidenciado em 2015. Mesmo não tendo responsabilidade dominante sobre os fatos apurados na Operação Lava Jato, fomos envolvidos em um sistema ilegal e ilegítimo de

CAMPO-TERRITÓRIO: revista de geografia agrária, v. 13, n. 30, p. 187-217, ago., 2000 
financiamento político-eleitoral. A indústria de construção pesada, pela complexidade dos projetos, pela soma de recursos envolvidos e pela proximidade entre agentes públicos e privados para sua execução, é altamente visada pelo setor público. Termina, algumas vezes, por aquiescer a práticas danosas para si e para a sociedade. Reconhecemos nossos erros e estamos aprendendo muito com eles. Mas isso não basta. É meu dever pedir desculpas a todos que possam ter sido prejudicados pelo envolvimento de nossa Organização em tais espisódios" (ODEBRECHT S.A., 2016, p. 12-13).

${ }^{23}$ Em Goiás, existem três unidades: Rio Claro (2009), no municipio de Caçu; Morro Vermelho (2010), no município de Mineiros; e Água Emendada (2011), no município de Perolândia. Em Mato Grosso, tem a unidade de Alto Taquari (2010), no município de mesmo nome. Em Mato Grosso do Sul existem três unidades: Elodorado (2008), no município de Rio Brilhante; Santa Luzia (2009), no município de Nova Alvorada do Sul; e Costa Rica (2011), no município de mesmo nome. Em São Paulo, além de dois escritórios, um na capital e outro em Campinas, existe a Fazenda Alcídia, no município de Teodoro Sampaio, e a Unidadade Conquista do Pontal, na regiao do Pontal do Paranaparema (ATVOS, 2018).

\section{REFERÊNCIAS}

ALMEIDA, Rômulo Barreto de. Traços da história econômica da Bahia no último século e meio. Revista de Desenvolvimento Econômico, Salvador, ano XI, n. 19, p. 82-101, jan., 2009 [1952].

ATVOS. Disponível em: <http://www.atvos.com/>. Acesso em: 23 jan. 2018.

BANCO CENTRAL DO BRASIL. Disponível em: <https://www.bcb.gov.br>. Acesso em: 5 jan. 2016.

BARROS, José Roberto Mendonça de. A experiência regional de planejamento. In: LAFER, Betty Mindlin (Org). Planejamento no Brasil. 5. ed. São Paulo: Perspectiva, 1987. 184 p. p. $111-137$.

BOLTANSKI, Luc. CHIAPELLO, Éve. O novo espírito do capitalismo. Tradução livre Ivone C. Beneditti; revisão técnica Basílio Sallum Jr. São Paulo: WMF Martins Fontes, 2009. $701 \mathrm{p}$.

BRASIL. Portaria n ${ }^{\circ}$ 1.719, de 23 de dezembro de 1994. Diário Oficial da União, Poder Executivo, Brasília-DF, 26 dez. 1994. Seção 1, p. 20.530.

BUAINAIN, Antônio Márcio. et al. Sete teses sobre o mundo rural brasileiro. Revista de Política Agrícola, Brasília-DF, ano XXII, n. 2, p. 105-121, abr./jun. 2013.

CAMACHO, Rodrigo Simão. Paradigmas em disputa na Educação do Campo. $806 \mathrm{f}$. (Doutorado Geografia). Presidente Prudente-SP: UNESP, 2013.

CASTRO, Moacir Werneck de. Missão na selva: a aventura brasileira de Emil Odebrecht. 2. ed. Rio de Janeiro: Versal, 2003. 176 p.

CHESNAIS, François. A mundialização do capital. Tradução Silvana Finzi Foá. São Paulo: Xamã, 1996. 335 p. 
GERMANI, Guiomar Inez. Condições históricas e sociais que regulam o acesso a terra no espaço agrário brasileiro. GeoTextos, Salvador, v. 2, n. 2, p. 115-148, dez. 2005.

Cuestión agraria y asentamineto de población em el área rural: la nueva cara de la lucha por la tierra. Bahia, Brasil (1964 -1990). (Doutorado em Geografia). Barcelona: Universidade de Barcelona, 1993.

GONÇALVES, Alicia Ferreira. Cultura \& mercado no contexto transnacional: uma etnografia da Tecnologia Empresarial Odebrecht. 336 p. (Doutorado em Ciências Sociais). São Paulo: UNICAMP, 2003.

HARVEY, David. O novo imperialismo. 6. ed. Tradução Adail Sobral; Maria Stela Gonçalves. São Paulo: Loyola 2012. 201 p.

A produção capitalista do espaço. Tradução Carlos Szlak. 2.ed. São Paulo: Annablume, 2005. (Coleção Geografia e Adjacências). 252 p.

JACOBINA, Ronaldo. O empresário que foi longe. Revista Muito, Salvador-Ba, p.1219, 5 out. 2008.

LAFER, Celso. O Planejamento no Brasil: Observações sobre o plano de metas (19561961). In: LAFER, Betty Mindlin (Org). Planejamento no Brasil. 5. ed. São Paulo: Perspectiva, 1987. 184 p. p. 29-50.

LEFEBVRE, Henri. A produção do espaço. Tradução Doralice Barros Pereira e Sérgio Martins (do original: La production de l'espace. 4.ed. Paris: Éditions Anthropos, 2000). Primeira versão: início - fev. 2006 [1974].

LIMA, Aline dos Santos. A territorialização do capital na lavoura de mandioca: a educação pelo trabalho da Aliança Estratégica do Amido no município de Laje (BA). 377 f. (Doutorado em Geografia). Salvador: UFBA, 2017.

MARTINS, José de Souza. O cativeiro da terra. São Paulo: Livraria Editoria Ciências Humanas, 1979. 157 p.

MARX, Karl. O capital: crítica da economia política: Livro 1: o processo de produção do capital. Tradução Rubens Enderle. São Paulo: Boitempo, 2013. 1895 p.

MARX, Karl; ENGELS, Friedrich. Manifesto comunista. Tradução Maria Arsênio da Silva. 6. ed. São Paulo: CHED, 1980 (Coleção polêmicas operárias: Série documentos). $57 \mathrm{p}$.

MITIDIERO JUNIOR, Marco Antônio. Crise do capital global, natureza e agronegócio. In: RAMOS FILHO, Eraldo da Silva. MITIDIERO JUNIOR, Marco Antônio. SANTOS, Laiany Rose Souza (Orgs.). Questão agrária e conflitos territoriais. São Paulo: Outras Expressões, 2016. 280 p. p. 17-35. (Coleção Território e Questão Agrária). 
MORAES, Antonio Carlos Robert. Bases da formação territorial no Brasil: o território colonial brasileiro no "longo" século XVI. São Paulo: Hucitec, 2000. (Estudos Históricos; 41). $432 \mathrm{p}$.

PRATA, Maria del Carmen López. A vida e a lida: estudos sobre trajetórias e projetos de vida de famílias de lavradores no interior do Estado da Bahia. (Mestrado em Sociologia). Salvador: UFBA, 1994.

ODEBRECHT AGROINDUSTRIAL. Relatório Anual da Odebrecht Agroindustrial Safra 2016/2017. São Paulo: Odebrecht Agroindustrial, 2017. 86 p.

. Relatório Anual da Odebrecht Agroindustrial Safra 2015/2016. São Paulo: Odebrecht Agroindustrial, 2016. 68 p.

Relatório Anual da Odebrecht Agroindustrial Safra 2014/2015. São Paulo:

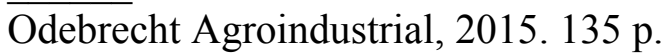

ODEBRECHT, Norberto. Desenvolvimento sustentável: a visão e a ação de um empresário: o caso do Baixo Sul da Bahia. Salvador: CRA, 2004. (Série construindo os recursos do amanhã, v. 5). 194 p.

Educação pelo trabalho: Tecnologia Empresarial Odebrecht. Salvador: Odebrecht, 1991. 564 p.

ODEBRECHT INFORMA ON LINE. Disponível: $<$ http://www.odebrechtonline.com.br>. Acesso em: 04 set. 2016.

ODEBRECHT S.A. Relatório Anual da Odebrecht S.A. 2017. Salvador: Odebrecht, 2018. 107 p.

. Relatório Anual da Odebrecht S.A. 2016. Salvador: Odebrecht, 2017. 119 p.

Relatório Anual da Odebrecht S.A. 2015. Salvador: Odebrecht, 2016. 121 p.

Relatório Anual da Odebrecht S.A. 2014. Salvador: Odebrecht, 2015. 81 p.

Relatório Anual da Odebrecht S.A. 2013. Salvador: Odebrecht, 2014. 84 p.

Relatório Anual da Odebrecht S.A. 2012. Salvador: Odebrecht, 2013. 77 p.

. Relatório Anual da Odebrecht S.A. 2011. Salvador: Odebrecht, 2012. 95 p.

Relatório Anual da Odebrecht S.A. 2010. Salvador: Odebrecht, 2011. 70 p.

Relatório Anual da Odebrecht S.A. 2009. Salvador: Odebrecht, 2010. 63 p.

Relatório Anual da Odebrecht S.A. 2008. Salvador: Odebrecht, 2009. 69 p. 
. Relatório Anual da Odebrecht S.A. 2007. Salvador: Odebrecht, 2008. 52 p.

Relatório Anual da Odebrecht S.A. 2006. Salvador: Odebrecht, 2007. 48 p.

. Relatório Anual da Odebrecht S.A. 2005. Salvador: Odebrecht, 2005.

. Relatório Anual da Odebrecht S.A. 2004. Salvador: Odebrecht, 2004.

. Relatório Anual da Odebrecht S.A. 2003. Salvador: Odebrecht, 2003.

Relatório Anual da Odebrecht S.A. 2002. Salvador: Odebrecht, 2002.

OLIVEIRA, Ariovaldo Umbelino de. A mundialização da agricultura brasileira. In: XII COLOQUIO INTERNACIONAL DE GEOCRÍTICA: Las independências y construcción de estados nacionales; poder, territorialización y socialización, siglos XIXXX, 12., 2012, Bogotá-Colômbia. Anais XII Coloquio Internacional de Geocrítica. Bogotá-Colômbia: UNC/Facultad de Ciencias Humanas-Departamento de Geografia, 2012. p. 1-15.

. A geografia Agrária e as transformações territoriais recentes no campo brasileiro. In: CARLOS, Ana Fani Alessandri. Novos caminhos da Geografia. São Paulo: Contexto, 2002. (Caminhos da Geografia) (p. 63-110).

. A agricultura brasileira: desenvolvimentos e contradições. In: BECKER, Bertha Koiffmann et.al (Orgs.). Geografia e meio ambiente no Brasil. São Paulo: Hucitec, 1995. p. 280-306.

ORGANIZAÇÃO ODEBRECHT. Disponível em: <http://odebrecht.com/>. Acesso em: 23 jan. 2018.

. Disponível em: <http://odebrecht.com/>. Acesso em: 24 mar. 2016.

Disponível em: <http://odebrecht.com/> Acesso em: 27 set. 2015.

PAULINO, Eliane Tomiasi. Terra e vida: a Geografia dos camponeses no norte do Paraná. 430 f. (Doutorado Geografia). Presidente Prudente-SP: UNESP, 2003.

POLÍCIA FEDERAL. Disponível em: <http://www.pf.gov.br/>. Acesso em: 11 abr. 2016.

REVISTA ODEBRECHT INFORMA. [S. I.]: Odebrecht S.A., 2004. Edição Histórica.

SANTOS, José Vicente Tavares dos. Colonos do vinho: estudo sobre a subordinação do trabalho camponês ao capital. São Paulo: Hucitec, 1978.

SANTOS, Milton. A natureza do espaço: técnica e tempo; razão e emoção. 2.ed. São Paulo: Hucitec, 1997 [1996]. 308 p. 
Por uma geografia nova: da crítica da geografia a uma geografia crítica. São Paulo: EdUSP, 2002 [1978]. (Coleção Milton Santos, v. 2). 288 p.

Espaço e método. 5. ed. São Paulo: EdUSP, 2008. (Coleção Milton Santos; 12). $120 \mathrm{p}$.

SÃO PAULO (Estado). Demonstrações financeiras da Odebrecht Terras S.A. Diário Oficial do Estado de São Paulo, Poder Executivo, São Paulo-SP, 25 jul. 2015. Seção Empresarial 125(136), p. 11.

SUZUKI, Júlio César. Geografia agrária: gênese e diversidade. MARAFON, Glaucio José; RUA, João; RIBEIRO, Miguel Ângelo (Orgs.). Abordagens teóricometodológicas em geografia agrária. Rio de Janeiro: EdUERJ, 2007. 330 p. p. 17-39.

WAIBEL, Leo. Princípios da colonização europeia no sul do Brasil. In: WAIBEL, Leo. Capítulos de Geografia Tropical e do Brasil. 2. ed. Rio de Janeiro: IBGE, 1979. 328 p. p. 225-277.

Anexo A - Genealogia da família Odebrecht

1. EMIL ODEBRECHT (1835-1912) + Bertha Bichels (1844-?). Tiveram 15 filhos:

1.1 EDMUNDO ODEBRECHT (1864-1908)

1.2 Mathilde Odebrecht (1866-?) + Gustav Baumgart. Tiveram 2 filhos:

1.2.1 Emilio Henrique Baumgart

1.2.2 Rudolf Baugmart

1.3 August Odebrecht (1868-?)

1.4 Oswaldo Odebrecht (1869-?) + Else Voigt. Tiveram 9 filhos:

1.4.1 Heinz Odebrecht

1.4.2 Bertha Odebrecht

1.4.3 Udo Odebrecht

1.4.4 Emílio Odebrecht

1.4.5 Arno Odebrecht

1.4.6 Alfons Odebrecht

1.4.7 Asta Odebrecht

1.4.8 Oswaldo Odebrecht

1.4.9 Rolf Odebrecht + Renate Sybille Odebrecht

1.4.1.1 Christiane Odebrecht Rupp + (?) 1.4.1.1.1 Marcos Schroeder

1.5 Rudolf Odebrecht (1871-?)

1.6 Helene Odebrecht (1872-?) + Rudolf Altenburg

1.7 Claerchen Odebrecht (1874-?)

1.8 Auguste Odebrecht (1878-?)

1.9 Woldemar Odebrecht (1879-?)

1.10 Edgard Odebrecht (1881-?)

1.11 Anne Marie Odebrecht (1884-?)

1.12 Hedwig Odebrecht (1886-?)

$1.13(?)$

$1.14(?)$

1.15 Adolf Odebrecht

2. EDMUNDO ODEBRECHT (1864-1908) + Cecília Altenburg. Tiveram 11 filhos: 
$2.1(?)$

2.2 EMÍLIO ODEBRECHT (1894-1962)

$2.3(?)$

$2.4(?)$

$2.5(?)$

$2.6(?)$

$2.7(?)$

$2.8(?)$

$2.9(?)$

$2.10(?)$

$2.11(?)$

3. EMÍLIO ODEBRECHT (1894-1962) + Hertha Hinsch. Tiveram 3 filhos:

3.1 Gerda Odebrecht

3.2 Erika Odebrecht

3.3 NORBERTO ODEBRECHT (1920-2014)

4. NORBERTO ODEBRECHT (1920-2014) + Iolanda Valladares Alves. Tiveram 5 filhos:

4.1 Norberto Odebrecht Júnior

4.2 Emílio Alves Odebrecht + Regina Bahia Odebrecht

4.2.1 Marcelo Bahia Odebrecht

4.2.2 Maurício Bahia Odebrecht

4.2.3 Mônica Bahia Odebrecht

4.2.4 Márcia Bahia Odebrecht Oliveira

4.3 Ilka Odebrecht + Francisco Peltier de Queiroz

4.3.1 Francisco Peltier de Queiroz Filho

4.3.2 Iolanda Peltier de Queiroz $+\mathrm{N}$ Neves da Rocha

4.3.3 Emílio Peltier de Queiroz

4.4 Martha Alves Odebrecht + Paulo Bastos de Queiroz

4.4.1 Paulo Odebrecht de Queiroz

4.4.2 Cristina Odebrecht de Queiroz Cidreira

4.4.3 Alexandre Odebrecht de Queiroz

4.4.4 Eduardo Odebrecht de Queiroz

4.5 Eduardo Alves Odebrecht + Maria da Glória Novis

4.5.1 Solange Novis Odebrecht

4.5.2 Juliana Novis Odebrecht Levita

4.5.3 Veronica Novis Odebrecht

4.5.4 Norberto Odebrecht Neto

Recebido em 21/05/2018.

Aceito para publicação em 26/03/2019. 